\title{
Indonesian primary care physicians profile in 2011: Did practicing hours and conversion program for family medicine differentiate their services and continuing medical education activities?
}

\author{
Indah S Widyahening ${ }^{1 *}$, Daniel M Thuraiappah², Tin Myo $\operatorname{Han}^{3}$ and Dhanasari Vidiawati ${ }^{1}$
}

\begin{abstract}
Background: In Indonesia, Family Medicine as a discipline is being developed through short courses since 12 years ago. A conversion program to become Family Physicians has been introduced recently. Among the 70,000 primary care physicians there are variety of practitioners, from new interns who start general practice to senior general practitioners. This study aims to describe the current Indonesian Primary Care Physicians (PCPs) profile which includes services provided and facilities as well as comparing the profile according to participation in the conversion program and practice hours.
\end{abstract}

Methods: A survey was carried out by using pre-tested, semi-structured and self-administered questionnaire among Indonesian primary care physicians (PCPs) who attended ASEAN Regional Primary Care Conference in Jakarta, November 2011. The survey elicited information regarding their practice environment, services provided, equipment, investigations provided, procedures, facilities and continuing medical education (CME) activities.

Results: Out of 240 PCPs participated, $65.4 \%$ (157/240) of them were family physicians and $67.1 \%$ (161/240) of them were full time practitioners (practice $>30$ hours per week). Services like body mass index (BMI) measurement, substance abuse program, respiratory function test, mental health assessment, and cardiovascular assessment were provided by less than $50 \%$ of the PCPs as well as some investigations like electrocardiograph (ECG), proctoscopy, ultrasound, visual examination and funduscopy. Family Physicians significantly provided more house call services (77\% vs 63\%; $p=0.01$ ), than those who are not. No other significant difference was found in the practice of the family physicians compare to non-family physicians.

Conclusions: The Indonesian PCPs were lacking in the provision of some particular medical procedures, management and follows up of acute and chronic conditions, and preventive medicine and health education. Improvement of primary health care has been seen globally as necessary effort in health systems reform and this information could provide guidance toward the efforts to improve the quality of primary care physicians in Indonesia.

Keywords: Primary health care, General practice, Family practice, Health service survey, Indonesia

\footnotetext{
* Correspondence: indah_widyahening@ui.ac.id

'Department of Community Medicine, Faculty of Medicine Universitas

Indonesia, Jl. Pegangsaan Timur 16, Jakarta 10430, Indonesia

Full list of author information is available at the end of the article
} 


\section{Background}

Primary care is one level of health system which provides first point of care to the population and has easy access, low cost, continuous, coordinated and comprehensive care as its core attributes [1]. General practitioners/family physicians hold a central role in provision of healthcare services in most countries even though there are variations with regard to the levels of training, organization and service deliveries [2].

Different surveys to describe the profile of primary care practice has been conducted in several countries [3-6]. However, none of these surveys described the primary care practice in South East Asian countries. Indonesia is the biggest country with the largest population within the South East Asian countries. The number of general practitioners (GP) in Indonesia is around 70,000 while the specialist is 16,000 . Currently, every medical school graduates in Indonesia is prepared to practice as GP after they complete a one year internship program. Family medicine is not yet recognized as a specialty. Other neighboring countries such as Malaysia, Singapore and the Philippines, have general practice vocational training program (3-4 year), commencing after a basic medical education degree [7]. To make the Indonesian GP's qualification equal with other South East Asian countries, a structured postgraduate training program is currently being developed. As part of the preliminary process, a conversion program is being conducted to accredit GPs who already implement certain level of family medicine approach in their clinical practice. The conversion program is intended for GPs who have been in practice for at least 5 years and undergo an assessment of competence for the GPs who want to improve their status to family practitioners [8]. They have to complete a form which serves as record of their past and current medical practice and professional activities. After the conversion, they become the member of the Indonesian Association of Family Physicians (PDKI) with status as Family Physicians and need to participate in continuing professional development program on a regular basis.

This survey is part of a surveys conducted in four countries (Indonesia, Malaysia, Myanmar and the Philippines) to assess the current Primary Care Physicians/General Practitioners profile and their CME activities. In this report we only describe the Indonesian data and aim to compare the profile of those participated in the conversion program with those who do not participated as well as comparing based on the practice hours.

\section{Methods}

A cross-sectional descriptive and analytic study was carried out by using pre-tested, semi-structured and selfadministered questionnaire among Indonesian primary care physicians (PCPs) who attended the 2nd ASEAN
Regional Primary Care Conference in Jakarta, November 2011. The survey form is modified from the Malaysian Quality Improvement Program which has detailed surveys on structure, clinical processes and clinical outcomes [9]. The modified version has been used to profile practicing doctors in Malaysia. The survey elicited information which reflect four areas of service provision provided by primary care: 1 ) as the doctor of first contact in health-related matters, 2) in minor surgical and investigative procedure, 3 ) in the management and follow-up of a broad range of acute and chronic diseases, and 4) in preventive medicine $[5,6]$. The items in the questionnaire were classified in to practice environment, services provided, equipment, investigations provided, procedures, facilities and continuing medical education (CME) activities in accordance with the Malaysian Private Healthcare Facilities and Services Act Regulation 2008 which is then adjusted to the Standard of Practice of the Indonesian Family Physicians.

A pilot test was done and modification of the questionnaires was done in accordance with the finding of the pilot test. Reliability of over all 46 items of the data collecting tool (Cronbach's alpha) was 0.804 . Indonesian PCPs who practiced more than 30 hours per week are defined as full time practitioners while those who practiced less than 30 hours per week are classified as parttime practitioners. The PCPs were also classified into family physicians who passed the conversion program and non- family physicians who have not yet attained the conversion program.

The questionnaire was put in the delegates pack together with an information leaflet on consent for survey participation. Returning of the self-completed questionnaire by responders was taken as their consent. The Health Research Ethics Committee of the Faculty of Medicine Universitas Indonesia reviewed and approved the study.

A cross analysis using chi-square or fisher test (as appropriate) was done to find out the association between practice hours, conversion program and their practices. All analyses were performed using the SPSS 11.0 (SPSS Inc., Chicago, IL).

\section{Results}

Total 240 Indonesian PCPs participated in the study; 144 of them (60\%) were female. Most of them (175/240, 73\%) practice in Java (the most populated island in Indonesia) or in the provincial capital cities of Indonesia. Out of 240, $65.4 \%(157 / 240)$ of them were Family Physicians and $67.1 \%(161 / 240)$ of them were full time practitioners. Majority $(150 / 157,95 \%)$ of the family physicians practiced more than 5 years and $83 \%(134 / 161)$ of full-time PCPs were the main practitioners in the clinic. 
The Family Physicians significantly provided more house call services ( $77 \%$ vs $63 \%$; $=0.01$ ), than non-family physicians. Certain aspects were found more in family physicians such as dispensing medicine in clinic, certifying workers for fitness, women's health services, family planning services, providing substance abuse program, cardiovascular assessment, prescribing herbal medicine to some patients, medical nutrition therapy, satisfactory with medical equipment they have, doing urine examination, blood glucose test, visual examination, fundoscopy, soft tissue infiltration, cosmetic surgery, and keeping medical record; but these variations were not statistically significant (Tables 1 and 2).

Fewer family physicians provide acupuncture (16\% vs $29 \% ; \mathrm{p}=0.02)$ and hypnotherapy ( $7 \%$ vs $16 \% ; \mathrm{p}=0.03)$ compare to non-family physicians.

There was significant differences between full-time practitioners and part-time practitioners with reference to emergency care services $(85 \%$. vs $70 \%-\mathrm{p}=0.01)$, in providing substance abuse program ( $42 \%$ vs $28 \%$; $\mathrm{p}=0.04)$, doing urine examination (75\% vs 62\%; $\mathrm{p}=0.04)$, blood glucose test $(90 \%$ vs $77 \%$; $<$ < 0.01$)$ and ECG (39\% vs $23 \%$; $\mathrm{p}=0.01$ ) at clinic, providing minor surgery $(89 \%$ vs $77 \%$; $=0.03)$ and soft-tissue infiltration ( $47 \%$ vs $32 \% ; \mathrm{p}=0.02)$; and keeping registers for chronic disease (68\% vs $53 \%$; 0.04 ) and electronic medical records ( $54 \%$ vs $41 \%$; $\mathrm{P}=0.04$ ).

Regarding continuing medical education for general practitioners, no statistically significant different was found between the family physicians vs non-family physicians and the full-time vs part-time practitioners (Table 2).

\section{Discussion}

This study demonstrates the variety of skills and services provided by some practitioners in order to examine whether any or all of the services which are essential in an Indonesian environment were provided. Fifty percent or less of the PCPs provides body mass index (BMI) measurement and cardiovascular assessment as well as providing substance abuse program and mental health assessment. Investigative procedures such as respiratory function test, electrocardiography, ultrasonography, visual examination with an ophthalmoscope and even proctoscopy are also low among the PCPs.

The range of services provided by primary care varies considerably from country to country. Boerma, et al. found that primary care physicians in western Europe generally have stronger role compare to those in the eastern Europe [5]. The practice among countries in eastern Europe itself shows considerable differences [6].

Our study shown that many of the Indonesian primary care physicians do not provide services usually carriedout by primary care physicians in other countries. With regard to the four areas of service provision provided by primary care as defined by Grielen et al., [6] we found that services provided by Indonesian PCP were especially lacking in the application of medical procedures such as minor surgical and investigative procedures, management and follows up of acute and chronic conditions, and preventive medicine and health education.

The low availability of certain investigative procedures such as respiratory function test, electrocardiography, ultrasonography, visual examination with an ophthalmoscope or proctoscopy might due to the cost of equipment and cost of services. When this survey was conducted, universal coverage had not been implemented in Indonesia thus higher proportion of Indonesian population was not covered by health insurance. Yet, it is possible to encourage the use of some equipment such as ophthalmoscope or simple respiratory function test which is quite affordable. Provision of those services determine the comprehensiveness of primary care services [10]; one of the role intended for primary care [11].

Non-communicable diseases including cardio-vascular diseases, diabetes mellitus, chronic respiratory problem, mental health problem and substance abuse are emerging as the major threat in Indonesia [12] and the PCPs were expected to be actively involved in managing those problems. Yet in this survey we found that low proportion of PCPs provide services that were highly relevant to those problems such as body mass index (BMI) measurement, cardiovascular assessment substance abuse program and mental health assessment.

It was found that Family Physicians tend to provide more house call services and less acupuncture and hypnotherapy compare to those who are not Family Physicians. Those who practice more than 30 hours per week tend to have facilities to cope with emergency care, providing substance abuse program, treadmill assessment, urine examination, blood glucose test, ECG, minor surgery and soft tissue infiltration, have separate register for chronic disease and electronic medical record when compared to those who practiced less than 30 hours a week.

This pilot study was limited in that it was conducted among a selected group of delegates who attended a conference. It is evident that this cross-sectional survey studied the primary care physicians who worked in the bigger cities of Indonesia and has shown that encouraging primary care physicians to submit to a conversion program has elevated the practitioners to a higher level of care in terms of skills and services in a developing country like Indonesia. Further this study has shown that longer hours of practice also improves provision of care by primary care practitioners possibly due to the higher number and variability of patients/cases managed by the physicians. As Roger Jones [13] argues, strengthening general practice especially with strong educational support is the basis of primary healthcare system and not secondary or tertiary care. Profiling general practice 
Table 1 Practice environment, services, investigation and procedures provided by primary care physicians (PCPs) in Indonesia ( $\mathrm{N}=240)$; comparison based on the participation in Family Medicine conversion program and practice hours

\begin{tabular}{|c|c|c|c|c|c|c|c|c|c|c|c|c|}
\hline & \multirow{2}{*}{\multicolumn{2}{|c|}{ Overall }} & \multicolumn{5}{|c|}{ PCPs classification } & \multicolumn{5}{|c|}{ Practice hours per week } \\
\hline & & & \multicolumn{2}{|c|}{$\begin{array}{l}\text { Family physicians* } \\
(\mathrm{N}=157)\end{array}$} & \multicolumn{2}{|c|}{$\begin{array}{l}\text { Non-Family } \\
\text { Physicians (N = 83) }\end{array}$} & \multirow[t]{2}{*}{$\mathrm{p}^{* * *}$} & \multicolumn{2}{|c|}{$\begin{array}{l}>30 \text { hours } \\
(N=161)\end{array}$} & \multicolumn{2}{|c|}{$\begin{array}{l}<30 \text { hours } \\
(N=79)\end{array}$} & \multirow[t]{2}{*}{$p^{* * *}$} \\
\hline & $\mathbf{n}$ & $\%$ & $\mathrm{n}$ & $\%$ & $\bar{n}$ & $\%$ & & $\mathrm{n}$ & $\%$ & $\mathrm{n}$ & $\%$ & \\
\hline \multicolumn{13}{|l|}{ Practice environment } \\
\hline Full time practice ${ }^{* *}$ & 161 & 67 & 102 & 65 & 59 & 71 & 0.34 & - & - & - & - & \\
\hline Practice $>5$ years & 221 & 92 & 150 & 96 & 71 & 86 & $<0.01$ & 148 & 92 & 73 & 92 & 0.9 \\
\hline Main practitioners in the clinic & 185 & 77 & 123 & 78 & 62 & 75 & 0.42 & 134 & 83 & 51 & 66 & $<0.01$ \\
\hline \multicolumn{13}{|l|}{ Services } \\
\hline Facilities for emergency care & 191 & 80 & 129 & 82 & 62 & 75 & 0.07 & 136 & 85 & 55 & 70 & 0.01 \\
\hline House call & 173 & 72 & 121 & 77 & 52 & 63 & 0.01 & 116 & 72 & 57 & 72 & 0.46 \\
\hline Dispensing Medicine in clinic & 191 & 80 & 128 & 82 & 63 & 76 & 0.35 & 130 & 81 & 61 & 77 & 0.81 \\
\hline Immunization & 170 & 71 & 110 & 70 & 60 & 72 & 0.88 & 121 & 75 & 49 & 62 & 0.1 \\
\hline Measuring BMI & 110 & 46 & 72 & 46 & 38 & 46 & 0.92 & 82 & 51 & 28 & 35 & 0.06 \\
\hline Certifying workers for fitness & 151 & 63 & 103 & 66 & 48 & 58 & 0.12 & 105 & 65 & 46 & 58 & 0.15 \\
\hline Women/reproductive health & 169 & 70 & 114 & 73 & 55 & 66 & 0.93 & 117 & 73 & 52 & 66 & 0.37 \\
\hline Family planning services & 198 & 83 & 135 & 86 & 63 & 76 & 0.05 & 133 & 83 & 65 & 82 & 0.88 \\
\hline Substance abuse program & 89 & 37 & 59 & 38 & 30 & 36 & 0.61 & 67 & 42 & 22 & 28 & 0.04 \\
\hline Respiratory function test & 78 & 33 & 47 & 30 & 31 & 37 & 0.32 & 56 & 35 & 22 & 28 & 0.51 \\
\hline Mental Health assessment & 129 & 54 & 83 & 53 & 46 & 56 & 0.73 & 92 & 57 & 37 & 47 & 0.13 \\
\hline Cardiovascular assessment & 127 & 53 & 85 & 54 & 42 & 51 & 0.36 & 91 & 57 & 36 & 46 & 0.16 \\
\hline Treadmill assessment & 52 & 22 & 31 & 20 & 21 & 25 & 0.29 & 34 & 21 & 18 & 23 & 0.9 \\
\hline Prescribe herbal medicine & 101 & 42 & 69 & 44 & 32 & 39 & 0.42 & 70 & 44 & 31 & 39 & 0.53 \\
\hline Medical nutrition therapy & 158 & 66 & 108 & 69 & 50 & 60 & 0.08 & 108 & 67 & 50 & 63 & 0.76 \\
\hline \multicolumn{13}{|l|}{ Equipment } \\
\hline Satisfactory with medical equipment they have & 144 & 60 & 99 & 63 & 45 & 54 & 0.1 & 103 & 64 & 41 & 52 & 0.2 \\
\hline \multicolumn{13}{|l|}{ Investigation } \\
\hline Urine examination & 170 & 71 & 114 & 73 & 56 & 68 & 0.41 & 121 & 75 & 49 & 62 & 0.04 \\
\hline Blood glucose test & 206 & 86 & 136 & 87 & 70 & 84 & 0.63 & 145 & 90 & 61 & 77 & $<0.01$ \\
\hline ECGs & 81 & 34 & 53 & 34 & 28 & 34 & 1 & 63 & 39 & 18 & 23 & 0.01 \\
\hline Proctoscopy & 39 & 16 & 25 & 16 & 14 & 17 & 0.58 & 29 & 18 & 10 & 13 & 0.51 \\
\hline Ultrasound & 68 & 28 & 44 & 28 & 24 & 29 & 0.91 & 46 & 29 & 22 & 28 & 0.88 \\
\hline Visual (visus) examination & 138 & 58 & 95 & 61 & 43 & 52 & 0.2 & 97 & 60 & 41 & 52 & 0.22 \\
\hline Funduscopy & 89 & 37 & 59 & 38 & 30 & 36 & 0.61 & 59 & 37 & 30 & 38 & 0.22 \\
\hline \multicolumn{13}{|l|}{ Procedures } \\
\hline Minor surgery & 204 & 85 & 132 & 84 & 72 & 87 & 0.7 & 143 & 89 & 61 & 77 & 0.03 \\
\hline Soft tissue infiltration & 101 & 42 & 67 & 43 & 34 & 41 & 0.79 & 76 & 47 & 25 & 32 & 0.02 \\
\hline Acupuncture & 49 & 20 & 25 & 16 & 24 & 29 & 0.02 & 33 & 21 & 16 & 20 & 0.97 \\
\hline Hypnotherapy & 24 & 10 & 11 & 7 & 13 & 16 & 0.03 & 14 & 9 & 10 & 13 & 0.34 \\
\hline Cosmetic Surgery & 35 & 15 & 24 & 15 & 11 & 13 & 0.7 & 20 & 12 & 15 & 19 & 0.3 \\
\hline
\end{tabular}

Legend:

*Family physicians are those passed the conversion program by the Indonesian Association of Family Physicians.

** Full-time practice is practice more than 30 hours per week

*** $p$ is calculated with chi-square or fisher test as appropriate. 
Table 2 Clinic facilities and continuing medical education activities of primary care physicians in Indonesia ( $\mathrm{N}=240$ ); comparison based on the participation in Family Medicine conversion program and practice hours

\begin{tabular}{|c|c|c|c|c|c|c|c|c|c|c|c|c|}
\hline & \multirow{2}{*}{\multicolumn{2}{|c|}{ Overall }} & \multicolumn{5}{|c|}{ PCPs classification } & \multicolumn{5}{|c|}{ Practice hours per week } \\
\hline & & & \multicolumn{2}{|c|}{$\begin{array}{l}\text { Family physicians* } \\
(\mathrm{n}=157)\end{array}$} & \multicolumn{2}{|c|}{$\begin{array}{l}\text { Non-family } \\
\text { Physicians }(n=83)\end{array}$} & \multirow[t]{2}{*}{$\mathrm{p}^{* *}$} & \multicolumn{2}{|c|}{$\begin{array}{l}>30 \text { hours } \\
(n=161)\end{array}$} & \multicolumn{2}{|c|}{$\begin{array}{l}<30 \text { hours } \\
(n=79)\end{array}$} & \multirow[t]{2}{*}{$\mathbf{p}^{* *}$} \\
\hline & $\mathbf{n}$ & $\%$ & $\bar{n}$ & $\%$ & $\mathbf{n}$ & $\%$ & & $\bar{n}$ & $\%$ & $\mathrm{n}$ & $\%$ & \\
\hline \multicolumn{13}{|l|}{ Facilities } \\
\hline Medical record & 222 & 93 & 147 & 94 & 75 & 90 & 0.42 & 147 & 91 & 75 & 95 & 0.54 \\
\hline Patients' Register & 224 & 93 & 150 & 96 & 74 & 89 & 0.06 & 152 & 94 & 72 & 91 & 0.34 \\
\hline Separated register for chronic disease & 152 & 63 & 94 & 60 & 58 & 70 & 0.26 & 110 & 68 & 42 & 53 & 0.04 \\
\hline Locking cupboard for dangerous drugs & 158 & 66 & 101 & 64 & 57 & 69 & 0.51 & 107 & 67 & 51 & 65 & 0.85 \\
\hline Having a computer/laptop & 222 & 93 & 144 & 92 & 78 & 94 & 0.53 & 150 & 93 & 72 & 91 & 0.58 \\
\hline Electronic Medical Record & 119 & 50 & 71 & 45 & 48 & 58 & 0.06 & 87 & 54 & 32 & 41 & 0.04 \\
\hline Internet access & 207 & 86 & 131 & 83 & 76 & 92 & 0.2 & 140 & 87 & 67 & 85 & 0.35 \\
\hline \multicolumn{13}{|l|}{ Continuing medical education for GPs } \\
\hline Post Graduate Qualification & 38 & 16 & 30 & 19 & 8 & 10 & 0.06 & 86 & 53 & 29 & 37 & 0.05 \\
\hline Short courses in Family Medicine & 171 & 71 & 129 & 82 & $42-$ & 51 & $<0.01$ & 114 & 71 & 57 & 72 & 0.82 \\
\hline Conversion program & 157 & 65 & - & - & - & - & - & 102 & 63 & 55 & 70 & 0.34 \\
\hline Reading > one journal per year & 214 & 89 & 143 & 91 & 71 & 86 & 0.31 & 142 & 88 & 72 & 91 & 0.76 \\
\hline Attending $>$ one ward round per year & 149 & 62 & 101 & 64 & 48 & 58 & 0.61 & 103 & 64 & 46 & 58 & 0.54 \\
\hline Attending > five talk or lectures per year & 144 & 60 & 90 & 57 & 54 & 65 & 0.35 & 102 & 63 & 42 & 53 & 0.27 \\
\hline $\begin{array}{l}\text { Attending one workshop/symposium \& conference per } \\
\text { year }\end{array}$ & 219 & 91 & 143 & 91 & 76 & 92 & 0.93 & 148 & 92 & 71 & 90 & 0.54 \\
\hline Attending a full course in the last five years & 205 & 85 & 138 & 88 & 67 & 81 & 0.24 & 136 & 85 & 69 & 87 & 0.46 \\
\hline $\begin{array}{l}\text { Literature search to answer patients' problem } \\
\text { (>1x/month) }\end{array}$ & 207 & 86 & 136 & 87 & 71 & 86 & 0.97 & 142 & 88 & 65 & 82 & 0.12 \\
\hline Participated in Quality Improvement Program & 195 & 81 & 133 & 85 & 62 & 75 & 0.17 & 134 & 83 & 61 & 77 & 0.11 \\
\hline
\end{tabular}

lends to assessing the current status in order to springboard methods of improving the system.

Differences between family physicians and non-family physicians were small with respect to range of services, facilities and continuing medical education. This was unexpected since conversion program was envisioned to recognize those already implement family medicine approach prior to structured Family Medicine training is made available. It appears that the checklist utilized in the conversion program failed to distinguish those who provide better range of services. Remedial action may be proposed including developing better instrument which better reflecting the area of services provided by PCPs followed by provision of structured trainings focusing on the essential services which are currently less provided.

With regard to the availability of formal postgraduate training program for primary care practice, Indonesia is still lagging compare to other member countries of the Association of South East Asian Nation (ASEAN) and the role of primary care is still weakly recognized $[2,7]$. With the national governments struggling to contain ever increasing health care costs, the gate keeper role (i.e. provision of first contact services) of primary care should be strengthened. Strengthening the gatekeeping function of the PCPs and implementation of referral system will improve the provision of comprehensive services $[5,14]$.

This is also in line with the current a movement of the ASEAN countries through establishment of the ASEAN Region Primary Care Physicians Association which one of the aim is "to work towards common standards for quality healthcare, education, training, accreditation and certification to set competencies for general practitioners/ family physicians" in the region. This study provide important information to support the movement.

\section{Conclusion}

The Indonesian PCPs in our survey were lacking in the provision of some particular medical procedures, management and follows up of acute and chronic conditions, and preventive medicine and health education. However, longer hours of practice improves provision of services by primary care physicians more than participation in 
family medicine conversion program. Improvement of primary health care has been seen globally as necessary effort in health systems reform [15]. The results of our study show in which area the role of the Indonesian PCPs is relatively weak and on which skills the emphasis needs to be placed. This can provide guidance for the development of training programs for GPs to meet the common standards of the ASEAN countries.

\section{Competing interests}

The authors declare that they have no competing interests.

\section{Authors' contributions}

DMT design the study and the questionnaire. ISW and DV did the data collection. ISW and TMH analyze the data and draft the initial manuscript. All authors critically reviewed the manuscript and involve in all revision. All authors read and approved the final manuscript.

\section{Authors' information}

Dr. Indah S. Widyahening, MSc, MSc-CMFM is a lecturer in the Department of Community Medicine, Faculty of Medicine Universitas Indonesia, Jakarta. She is also a national board member of the Association of the Indonesian Family Physicians (PDKI).

Prof. Dr. Daniel M Thuraiappah, PJM, DPMS, AMN, SSA, BSc, MBBChBAO, MAFP, FAFP,FRACGP, FCGP(SL), FRCPE, FAMM is currently the President of Academy of Family Physicians of Malaysia. He is also a Professor in the Family Medicine Department, MAHSA University College, Malaysia.

Tin Myo Han M.B.B.S, M.Med.Sc (PH), MPH, CCFM, D.F.M is the Secretary of International Relations of the Myanmar Medical Association- General Practitioners' Society. She is also an Assistant Professor in the Medical Statistics Unit, Faculty of Dentistry, International Islamic University, Malaysia.

DR. Dr. Dhanasari Vidiawati, MSc-CMFM is a lecturer in the Department of Community Medicine, Faculty of Medicine Universitas Indonesia, Jakarta. She is also a member of Association of the Indonesian Family Physicians (PDKI) and the National Board for the advancement of the primary care physicians education.

\section{Acknowledgement}

The authors would like to acknowledge the Association of the Indonesian Family Physicians (PDKI) who provide access for the data collection.

\section{Author details}

${ }^{1}$ Department of Community Medicine, Faculty of Medicine Universitas Indonesia, J. Pegangsaan Timur 16, Jakarta 10430, Indonesia. ${ }^{2}$ Academy of Family Physicians of Malaysia and Family Medicine Department, MAHSA University College, Kuala Lumpur, Malaysia. ${ }^{3}$ Myanmar Medical AssociationGeneral Practitioners' Society. Medical Statistics Unit, Faculty of Dentistry, International Islamic University, Kuala Lumpur, Malaysia.

Received: 14 October 2013 Accepted: 8 December 2014

Published online: 20 December 2014

\section{References}

1. Starfield B: Is primary care essential? Lancet 1994, 344(8930):1129-1133.

2. Hays R, Pong LT, Leopando Z: Primary care in the Asia-Pacific region: challenges and solutions. Asia Pac Fam Med 2012, 11(1):8. Epub 5 October 2012.

3. Valderas J, Starfield B, Forrest C, Sibbald B, Roland M: Ambulatory care provided by office-based specialists in the United States. Ann Fam Med 2009, 7(2):104-111.

4. Hider P, Lay-Yee R, Crampton P, Davis P: Comparison of services provided by urban commercial, community-governed and traditional primary care practices in New Zealand. J Health Serv Res Policy 2007, 12(4):215-222.

5. Boerma W, van der Zee J, Fleming D: Service profiles of general practitioners in Europe. European GP Task Profile Study. Br J Gen Pract 1997, 47(421):481-486.

6. Grielen S, Boerma W, Groenewegen P: Task profiles of general practitioners in Central and Eastern Europe. Eur J Pub Health 2000, 10(4):249-254.
7. Hays RB, Morgan S: Australian and overseas models of general practice training. Med J Aust 2011, 194(11):S63-S66.

8. Wonodirekso S, Pattiradjawane D: The Role of the Ministry of Health in Empowerment and Career Development of Primary Physician to Achieve "MDGs" Targets. J Indones Med Assoc 2010, 60(3):101-106.

9. Academy of Family Physicians of Malaysia: Quality Improvement Program. Kuala Lumpur: Academy of Family Physicians of Malaysia; 2013. [updated 2013; cited 2013]; Available from: http://elms.afpm.org.my/portal/web/ guest/qip.

10. Kringos DS: The strength of primary care in Europe. Utrecht, the Netherlands: NIVEL; 2012.

11. Starfield B: Primary Care: balancing health needs, services, and technology. New York: Oxford University Press, Inc; 1998.

12. World Health Organization Regional Office for South-East Asia: Country profile: Indonesia. 11 Health questions about the 11 SEAR countries. New Delhi: World Health Organization Regional Office for South-East Asia; 2007.

13. Jones R: Strong medicine: research, education, and patient care in general practice. Br J Gen Pract 2010, 60(571):75-76.

14. Boerma W, Verhaak $P$ : The general practitioner as the first contacted health professional by patients with psychosocial problems: a European study. Psychol Med 1999, 29(3):689-696.

15. World Health Organization: Primary health care now more than ever. Geneva: World Health Organization; 2008.

\section{Submit your next manuscript to BioMed Central and take full advantage of:}

- Convenient online submission

- Thorough peer review

- No space constraints or color figure charges

- Immediate publication on acceptance

- Inclusion in PubMed, CAS, Scopus and Google Scholar

- Research which is freely available for redistribution 